\title{
24. EVALUATION OF HYDROGEOLOGIC PROPERTIES OF THE BARBADOS ACCRETIONARY PRISM: A SYNTHESIS OF LEG 156 RESULTS ${ }^{1}$
}

\author{
G. Zwart, ${ }^{2}$ W. Brückmann, ${ }^{3}$ K. Moran, ${ }^{4}$ A.K. MacKillop, ${ }^{5}$ A.J. Maltman, ${ }^{6}$ A. Bolton, ${ }^{6}$ \\ P. Vrolijk, ${ }^{7}$ T. Miller, ${ }^{7}$ M.J. Gooch, ${ }^{7}$ and A. Fisher ${ }^{2}$
}

\begin{abstract}
In situ and laboratory studies of permeability, conducted by Ocean Drilling Program scientists from Leg 156, provide constraints on parameters controlling the hydrogeologic system in the Barbados accretionary prism. Results from these studies indicate that core-scale and formation-scale permeability values differ by at least several orders of magnitude and are dependent on pore-fluid pressure and effective stress conditions. Direct measurement from packer experiments and indirect evidence from consolidation tests suggest that pore-fluid pressures are commonly above hydrostatic values and approach lithostatic values within the décollement zone. Permeability and fluid pressure conditions in the Barbados accretionary prism reflect the complexity of the hydrogeologic system of such an active tectonic environment.
\end{abstract}

\section{INTRODUCTION}

The dynamic interplay between hydrogeologic and tectonic conditions is key to understanding the complexity of deformational processes in tectonically active environments. Movement of pore fluids influences diagenetic processes, which can result in variations in the strength of rocks and sediments. Thermal and chemical characteristics of the pore fluids play a crucial role in controlling cementation, dissolution, or alteration of minerals. Pore-fluid pressure is also an important parameter in influencing failure conditions and deformation mechanisms. Reduction of effective stress by overpressuring results in alteration of failure conditions (Hubbert and Rubey, 1959). Localization of overpressures can determine the location and distribution of faulting. Knowledge of spatial and temporal distribution of fluid flow and fluid pressure would illuminate important aspects of the link between hydrogeologic conditions and potential modes of deformation.

The goals of Ocean Drilling Program (ODP) Leg 156 were to obtain direct and indirect measurements of hydrogeologic conditions within an active accretionary complex. To evaluate the magnitude and distribution of fluid flow and pressure, it is necessary to estimate the permeability of the sedimentary material, as well as fluid pressure conditions. Laboratory measurements provided data on core-scale permeability from Sites 948 and 949, and in situ packer experiments provided data on formation-scale permeability. Collective results of core-scale and in situ permeability tests from Leg 156 suggest the existence of a hydrogeologic environment that appears to be neither isotropic nor homogeneous.

'Shipley, T.H., Ogawa, Y., Blum, P., and Bahr, J.M. (Eds.), 1997. Proc. ODP, Sci. Results, 156: College Station. TX (Ocean Drilling Program).

${ }^{2}$ Earth Sciences Department, University of California, Santa Cruz, CA 95064 U.S.A. gretchen@earthsci.ucsc.edu

${ }^{3}$ GEOMAR Research Center Marine Geosciences, Kiel, Federal Republic of Germany.

${ }^{4}$ Geological Survey of Canada, Bedford Institute of Oceanography, Dartmouth, N.S., Canada.

${ }^{5}$ Ocean Drilling Program, Texas A\&M University, College Station, TX 77845, U.S.A.

${ }^{6}$ University of Wales, Institute of Earth Studies, Aberystwyth, Dyfed SY23 3DB, Wales, United Kingdom.

${ }^{7}$ Exxon Production Research Co., Houston, TX 77252, U.S.A.

\section{Tectonic Setting}

The Barbados accretionary wedge grows as the Caribbean Plate overrides the North American Plate, scraping off and incorporating sediments carried atop the oceanic crust. A convergence rate of 19 $\mathrm{mm} / \mathrm{yr}$ (Stein et al., 1988) has resulted in the development of an accretionary wedge that is on the order of $200 \mathrm{~km}$ wide and up to $20 \mathrm{~km}$ thick south of the Tiburon rise. The topographic relief of the Tiburon rise blocks northward sediment transport. Consequently, the accretionary prism to the north is narrower $(\sim 100 \mathrm{~km})$ and thinner (up to $\sim 10 \mathrm{~km}$ ). Drilling programs have focused on the toe of the accretionary wedge where the décollement, which marks the plate boundary, is accessible at subseafloor depths of less than $600 \mathrm{~m}$.

ODP Leg 156 revisited the general location of two previous drilling expeditions: Deep Sea Drilling Program (DSDP) Leg 78A and ODP Leg 110. In this region, the incoming sediments are predominantly clay and claystones of ages less than $60 \mathrm{Ma}$. Roughly half of the incoming sediments are being accreted, whereas the remainder is subducting along with the oceanic crust. The oceanic crust is on the order of $90 \mathrm{Ma}$. The décollement zone, which marks the boundary between the Caribbean and North American plates, is characterized by the presence of scaly fabric in the poorly lithified claystone (Shipboard Scientific Party, 1995a). A lithologic boundary between Units II and III was identified within the décollement zone. This boundary coincides with a change from relatively homogeneous clay content above and more variable clay content below. The variable clay content reflects the presence of turbidites in Unit III (Shipboard Scientific Party, 1995a). In addition, smectite content decreases down through the décollement zone and reaches a sharp minimum at its base (Underwood and Deng, Chapter 1, this volume).

The location of Site 948 coincides with the location of Site 671 (Fig. 1), $4.5 \mathrm{~km}$ west of the deformation front. Coring from 421 meters below sea floor (mbsf) to a total depth of 592 mbsf included all of the structurally defined décollement zone from 498 to 529 mbsf. Excellent core recovery (94\%) allowed for detailed analysis of geologic structure and mineralogy. Site 949 was located $2 \mathrm{~km}$ northeast of Site 948 (Fig. 1). Poor core recovery (39\%) from the cored interval (246-464 mbsf) limits the resolution of the décollement zone location at this site. Two cores (Cores 19X and 22X) were determined to be within the décollement domain. Core $22 \mathrm{X}$ fortuitously contained the lithologic boundary between Units II and III. The total extent of the décollement or the possible presence of additional fault 


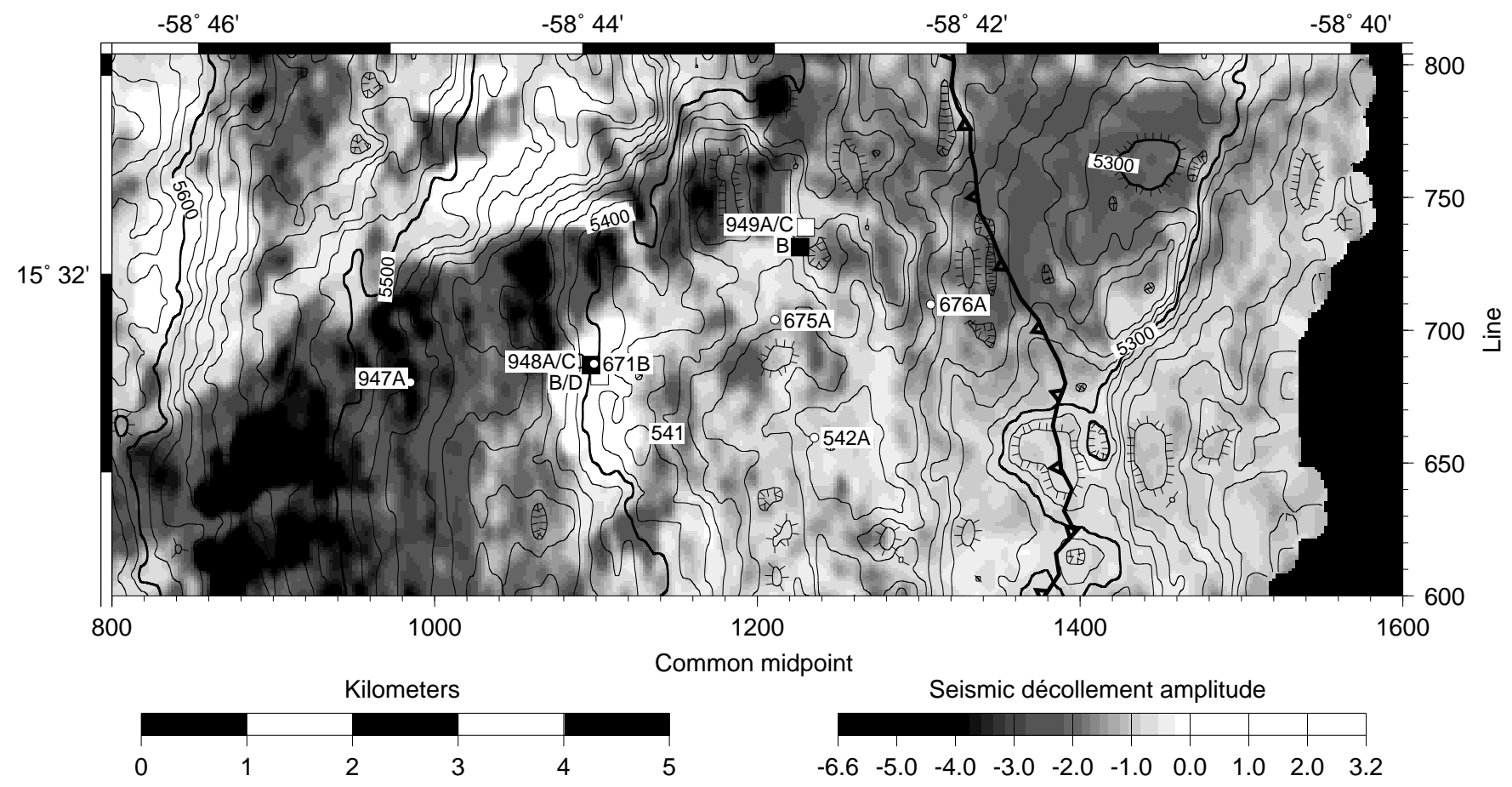

Figure 1. Map of seismic amplitude along the décollement around Leg 156 drill sites. DSDP and ODP sites are shown with small circles. Holes at which packer experiments were conducted are indicated with large black squares. Holes from which cores were obtained are indicated with large white squares.

splays could not be determined. Whole-round cores for laboratory permeability and consolidation tests were collected at both sites. In situ permeability tests were conducted as well.

\section{METHODS AND SAMPLE LOCATIONS}

Shore-based permeability and consolidation tests were conducted on samples of two whole-round cores from Site 948 (P. Vrolijk, unpubl. data) and six whole-round cores from Site 949 (Brückmann et al., Chapter 7, this volume; A.J. Maltman, unpubl. data; P. Vrolijk, unpubl. data). Table 1 lists the position of each whole-round core along with corresponding grain size and X-ray data. Subsequent references to individual samples of whole-round cores will use the Sample I.D. listed in Table 1. Figure 2 shows the schematic locations of samples at Sites 948 and 949 . Samples were typically quite homogeneous and cut from the most coherent sections of whole-round cores. To assess the magnitude of bulk or formation permeability and of fluid pressure, in situ hydrologic tests were conducted at both sites (Fisher and Zwart, Chapter 15, this volume). Figure 2 also indicates the extent of boreholes used during in situ permeability testing.

\section{Core-Scale Permeability Measurements}

The following section contains a brief explanation of methods used for permeability determination in each of the studies.

\section{Brückmann et al. (Chapter 7, this volume)}

One-dimensional (1-D) consolidation tests were conducted in a back-pressured consolidometer on samples of three whole-round cores from Site 949. Each sample was $6.2 \mathrm{~cm}$ in diameter and $2 \mathrm{~cm}$ high. Two of the samples (WB19X-1 and WB 22X-1) were from within the décollement domain, and the third (WB 15X-5) was from the prism domain. Permeability was measured at individual load steps using low-gradient flow tests (Olsen et al., 1985). Additional estimates of permeability were determined from the consolidation response of the samples based on Terzaghi's 1-D consolidation theory (Brückmann, et al., Chapter 7, this volume). Fresh water was used as the pore fluid and as the medium for generating confining pressure. The maximum effective stresses (preconsolidation stress- $P_{c}^{\prime}$ ) experienced by the sediments were determined for each sample based on the Casagrande construction (Holtz and Kovacs, 1981). An additional permeability test on a fourth sample (WB 2X-1, from the prism domain) was conducted in a triaxial cell at an effective stress of $10 \mathrm{kPa}$, using the low-gradient flow method.

\section{Vrolijk et al. (unpubl. data)}

One-dimensional consolidation tests were performed on samples of two whole-round cores from Site 948 and one whole-round core from Site 949. One of the cores from Site 948 was from within the prism above the décollement zone (PV 3X-3), and one was from the underthrust sequence (PV 13X-3). The core from Site 949 was from the prism domain (PV 3X-2). Samples $2.5 \mathrm{~cm}$ in diameter and $\sim 5 \mathrm{~cm}$ high were placed between load plates and jacketed with polyolefin, heatshrink tubing. The samples were then put in a triaxial test cell, and a confining pressure of $70 \mathrm{kPa}$ was applied. The sample was backpressured to $350 \mathrm{kPa}$, to dissolve any air remaining in the porepressure system. Simultaneously, the confining pressure was increased to $420 \mathrm{kPa}$, resulting in an initial effective stress value of 70 $\mathrm{kPa}$. A sequence of variable stress increments was then applied to each sample. Permeability was determined from the consolidation response, based on a modified version of Terzaghi's 1-D consolidation theory, which uses hydrostatic compressibility instead of the corresponding 1-D coefficient of compressibility. This modification reflects the fact that volume response to pressure changes are not limited to the vertical direction in the triaxial cell. The change in slope 
Table 1. Index of samples used in laboratory permeability and consolidation tests.

\begin{tabular}{|c|c|c|c|c|c|c|c|c|c|c|c|c|c|}
\hline \multirow[b]{2}{*}{$\begin{array}{l}\text { Sample } \\
\text { ID }\end{array}$} & \multirow[b]{2}{*}{$\begin{array}{l}\text { Core, section, } \\
\text { interval }(\mathrm{cm})\end{array}$} & \multirow[b]{2}{*}{$\begin{array}{l}\text { Depth } \\
\text { (mbsf) }\end{array}$} & \multicolumn{4}{|c|}{ Grain-size data* } & \multicolumn{7}{|c|}{ X-ray diffraction data ${ }^{\dagger}$} \\
\hline & & & $\begin{array}{l}\text { Depth } \\
\text { (mbsf) }\end{array}$ & $\begin{array}{l}\text { Sand } \\
\text { (wt } \%)\end{array}$ & $\begin{array}{c}\text { Silt } \\
(\mathrm{wt} \%)\end{array}$ & $\begin{array}{l}\text { Clay } \\
(\mathrm{wt} \%)\end{array}$ & $\begin{array}{l}\text { Depth } \\
\text { (mbsf) }\end{array}$ & $\begin{array}{c}\text { Smectite } \\
\text { (wt\%) }\end{array}$ & $\begin{array}{l}\text { Illite } \\
(w t \%)\end{array}$ & $\begin{array}{l}\text { Kaolinite } \\
\text { (wt } \%)\end{array}$ & $\begin{array}{l}\text { Quartz } \\
\text { (wt } \% \text { ) }\end{array}$ & $\begin{array}{l}\text { Plagioclase } \\
\text { (wt } \%)\end{array}$ & $\begin{array}{l}\text { Calcite } \\
\text { (wt } \%)\end{array}$ \\
\hline & $156-948 \mathrm{C}-$ & & & & & & & & & & & & \\
\hline PV $3 X-3$ & $3 \mathrm{X}-3,89-102^{\mathrm{V}}$ & 434.39 & 434.56 & 1.1 & 6.5 & 92.3 & 433.51 & 55.6 & 8.4 & 1.7 & 29.7 & 4.6 & 0.0 \\
\hline PV $13 X-3$ & $13 X-3,60-73^{v}$ & 530.40 & 531.06 & 0.2 & 7.5 & 92.3 & 530.40 & 14.1 & 49.1 & 11.8 & 24.9 & TR & 0.0 \\
\hline & 156-949B- & & & & & & & & & & & & \\
\hline AM 2X-1 & $2 \mathrm{X}-1,28-42^{\mathrm{M}}$ & 254.08 & 254.72 & 0.0 & 9.4 & 90.6 & 254.08 & 20.9 & 37.0 & 6.7 & 22.4 & 3.2 & 9.9 \\
\hline WB $2 X-2$ & $2 \mathrm{X}-2,72-88^{\mathrm{B}}$ & 256.02 & 255.51 & 3.6 & 8.3 & 88.1 & 256.02 & 46.3 & 14.7 & 5.5 & 28.9 & 4.6 & 0.0 \\
\hline PV 3X-2 & $3 \mathrm{X}-2,87-101^{\mathrm{V}}$ & 265.87 & 266.35 & 0.0 & 10.0 & 90.0 & 265.87 & 34.2 & 34.2 & 5.3 & 26.0 & 0.3 & 0.0 \\
\hline WB $15 X-5$ & $15 X-5,28-44^{\mathrm{B}}$ & 366.23 & 366.41 & 0.0 & 9.3 & 90.7 & 366.18 & 47.2 & 9.9 & 3.5 & 26.4 & 13.1 & 0.0 \\
\hline WB $19 X-1$ & $19 X-1,33-50^{\mathrm{B}}$ & 399.20 & 399.65 & 2.9 & 11.9 & 85.1 & 399.13 & 51.1 & 6.3 & 5.6 & 30.7 & 6.3 & 0.0 \\
\hline WB $22 \mathrm{X}-1$ & $22 \mathrm{X}-1,130-146^{\mathrm{B}}$ & 428.75 & 427.67 & 1.4 & 6.6 & 92.0 & 428.70 & 43.8 & 14.9 & 7.0 & 30.6 & 3.7 & 0.0 \\
\hline
\end{tabular}

Notes: In cases where data are not determined for a given sample, grain-size and X-ray data are reported for the closest sample. $*=$ grain-size data are from Meyer and Fisher, Chapter 27, this volume. ${ }^{\dagger}=$ X-ray diffraction data are from Shipboard Scientific Party (1995a, 1995b). ${ }^{\mathrm{V}}=$ tests conducted by Vrolijk, Miller, and Gooch at Exxon Production Research Co., Houston, TX 77252, U.S.A. ${ }^{\mathrm{M}}=$ tests conducted by Maltman and Bolton at University of Wales, Institute of Earth Studies, Aberystwyth, Dyfed SY23 3 DB, Wales. ${ }^{\mathrm{B}}=$ tests conducted by Brückmann, Moran, and MacKillop at Geological Survey of Canada, Bedford Institute of Oceanography, Dartmouth, N.S., Canada. TR = trace.

of a plot of void ratio vs. effective stress was assumed to indicate maximum effective stresses (preconsolidation stress- $P_{c}{ }^{\prime}$ ) experienced by the sediment for each of the three samples (Atkinson and Bransby, 1978). A second sample from whole-round core (PV 13X3 ) was subjected to a constant-head permeability test at an effective stress of $241 \mathrm{kPa}$. The pore fluid was saline, whereas the confining fluid in the triaxial cell was oil.

\section{Maltman et al. (unpubl. data)}

Permeability was measured on one sample from $254.1 \mathrm{mbsf}$ at Site 949 (AM 2X-1). Low gradient ( $25 \mathrm{kPa})$, constant-rate flow tests were conducted in a triaxial cell on a $3.8 \mathrm{~cm}$ diameter, $7.6 \mathrm{~cm}$ long cylindrical subsample of the whole-round core at a variety of effective stress conditions. Flow of distilled water was introduced along the cylinder axis, which corresponds to a vertical orientation within the borehole. The first set of measurements varied effective stress by maintaining constant confining pressure while varying the pore pressure within the sample. The second set of measurements varied effective stress by maintaining constant pore pressure and varying confining pressure.

\section{In Situ Permeability Measurements}

In situ permeability tests were conducted at Sites 948 and 949 during ODP Leg 156. A drill-string packer was used to test the hydrologic properties of an isolated interval of the boreholes including the décollement zone (Fisher and Zwart, Chapter 15, this volume). Pressures within in the isolated intervals were manipulated by instantaneous pressure pulses or constant pumping rates. The pressure response was monitored by a downhole pressure gauge for the duration of these tests. Pressure vs. time records were then analyzed to determine the bulk permeability of the isolated interval. Permeability values were determined using data from a total of fourteen tests conducted at Site 948 and eight tests conducted at Site 949.

\section{RESULTS}

\section{Laboratory Measurements}

Laboratory measurements of permeability for all samples are listed in Table 2. Permeability values as inferred from consolidation test response are listed as well. For the samples considered here, permeability values based on calculations derived from consolidation response generally overestimate laboratory measurement values (Fig. $3 \mathrm{~A})$. Differences between the two values for a given consolidation step range from negligible up to a factor of 20. A single measured val- ue from the study of Vrolijk et al. (1991; PV 13X-3) is almost twice the inferred value. In this case, the inferred permeability underestimates the measured permeability. In general, correlations of inferred permeabilities to measured permeabilities are better for coarser materials than for fine-grained sediments (Brückmann et al., Chapter 7, this volume). Because the total clay content for each sample exceeds $50 \%$, based on X-ray diffraction data, and because the data presented here show no systematic relationship between calculated and measured values, further discussion will focus on actual permeability measurements. Lab permeability data are presented in relation to effective stress to allow comparison with in situ data. To facilitate comparison with other lab data, they are also presented in relation to void ratio and porosity.

All of the measured permeabilities fall within a range of $3 e-19$ to $8 \mathrm{e}-16 \mathrm{~m}^{2}$ (Table 2). Permeabilities for one sample from the prism domain (WB 15X-5) exhibit a pronounced increase as effective stress decreases from $\sim 800$ to $\sim 200 \mathrm{kPa}$ (Fig. 3A). Two samples from the décollement domain (WB 19X-1 and WB 22X-1) change less than an order of magnitude for similar effective stress ranges. A single measurement for a sample from Core 156-949B-2X (WB 2X-1) at very low effective stress $(10 \mathrm{kPa})$ has a permeability approaching $1 \mathrm{e}-16$ $\mathrm{m}^{2}$. Multiple measurements on a second sample from Core 156949B-2X (AM 2X-1) show a permeability decrease of over an order of magnitude from $4.8 \mathrm{e}-18 \mathrm{~m}^{2}$ to $1.0 \mathrm{e}-19 \mathrm{~m}^{2}$, as effective stress was increased from 80 to $1215 \mathrm{kPa}$ (Fig. 3B).

The two methods used for reproducing effective stress in tests on Sample AM 2X-1 (constant confining stress or constant pore pressure) yielded virtually identical results. In this series of tests, an abrupt change in permeability was observed between 200 and 300 $\mathrm{kPa}$ effective stress (Fig. 3B). At higher effective stresses, permeability decreases from roughly $2 \mathrm{e}-18 \mathrm{~m}^{2}$ at a constant rate of about $0.5 \mathrm{e}-18 \mathrm{~m}^{2}$ for each $100 \mathrm{kPa}$ increase. At lower effective stresses, the rate of decrease is very slightly greater.

Effective stress in the Barbados accretionary prism can potentially reflect pore pressures ranging from hydrostatic to lithostatic values. The vertical effective stress values, based on hydrostatic fluid pressures, range from 1760 to $4089 \mathrm{kPa}\left(P_{o}^{\prime}\right.$ in Table 2). Past consolidation stress $\left(P_{c}^{\prime}\right.$ in Table 2$)$ is an indication of the maximum effective stress an individual sample has been subjected to in situ. The overconsolidation ratios $\left(\mathrm{OCR}=P_{c}^{\prime} / P_{o}{ }^{\prime}\right)$ indicate that all samples are underconsolidated. In other words, $P_{c}^{\prime}$ is consistently less than $P_{o}^{\prime}$, and fluid pressures must be in excess of hydrostatic.

Changes in void ratio with log effective stress tend to be linear for results from conventional soil mechanics tests (Lambe and Whitman, 1969). As expected, void ratio exhibits a linear relationship with the log of effective stress for all samples, including both measured and inferred permeabilities (Fig. 4). Void ratio changes by around 0.1 for 

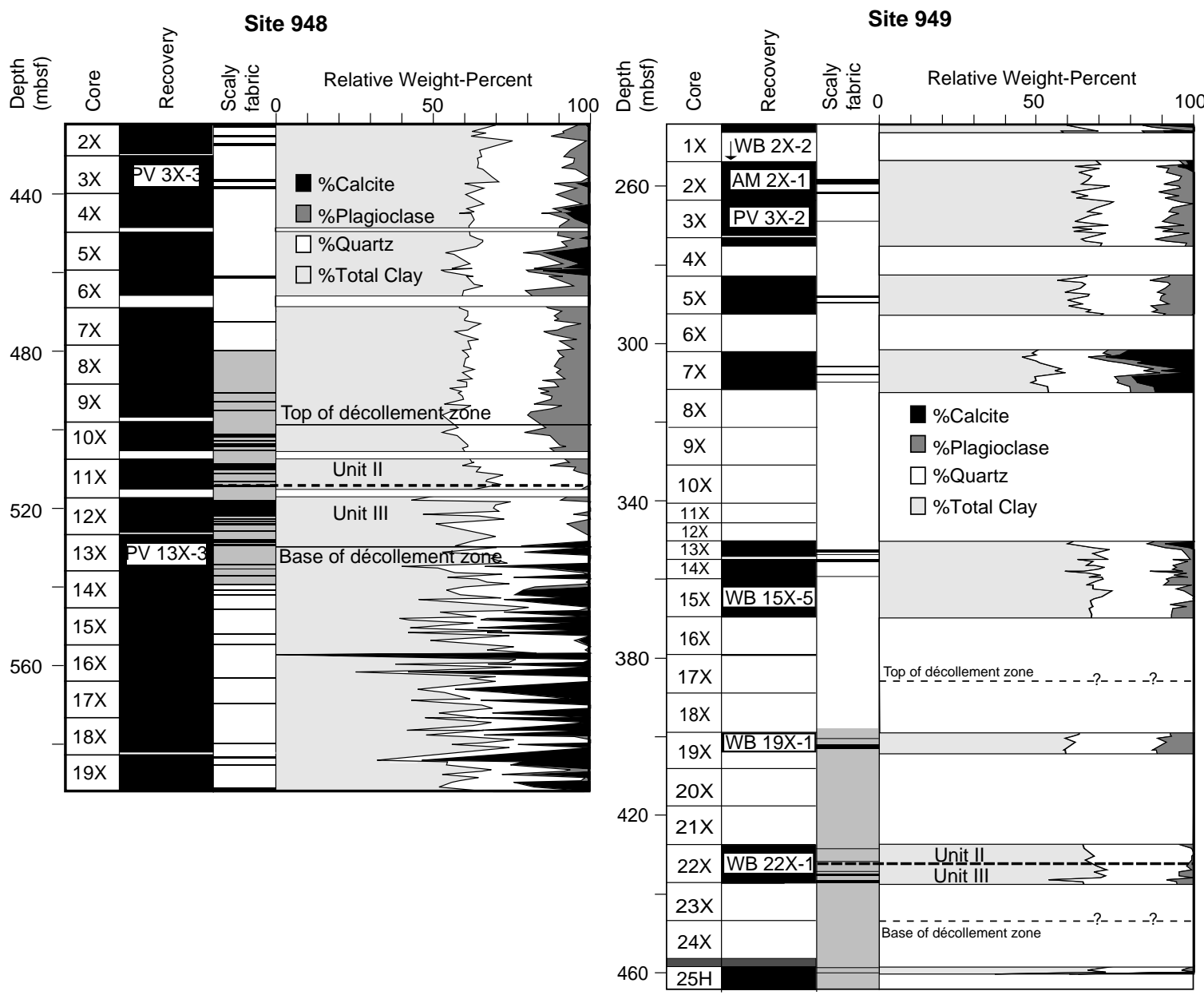

Figure 2. Summary diagrams showing Sample I.D. (see Table 1) and location of cores used for permeability tests. Zones of scaly fabric are indicated by black lines of variable thickness. The gray shaded region within the scaly fabric column shows the extent of boreholes used during in situ hydrologic testing. Relative mineral abundances are based on shipboard X-ray diffraction data.

each order of magnitude change in permeability. Corresponding values of porosity change between 0.01 and 0.1 for each order of magnitude change in permeability (Fig. 5).

\section{In Situ Permeability Measurements}

Bulk-permeability values, determined from all analyses of packer testing at Sites 948 and 949, range over almost three orders of magnitude, from $6.4 \mathrm{e}-16$ to $3.5 \mathrm{e}-13 \mathrm{~m}^{2}$ (Table 3). Effective stresses vary between a minimum of $118 \mathrm{kPa}$ and a maximum of $3678 \mathrm{kPa}$. Bulkpermeability appears to exhibit an increasing trend with decreasing effective stress (Fisher and Zwart, Chapter 15, this volume). Results from the most reliable tests indicate that permeability increases two orders of magnitude as effective stress decreases from $\sim 1600$ to $\sim 400$ $\mathrm{kPa}$ (Fig. 6). In addition, fluid pressures in excess of hydrostatic were observed within the décollement zone during packer experiments (Fisher and Zwart, Chapter 15, this volume).

\section{DISCUSSION}

In the Barbados accretionary prism, geochemical and thermal anomalies that correlate to fault-zone locations (the décollement zone in particular) indicate that these faults act as high-permeability conduits (Vrolijk et al., 1991, Fisher and Hounslow, 1990). Numerical modeling suggests that permeabilities within the décollement zone must be many orders of magnitude above background values to produce the observed geochemical anomalies (Bekins et al., 1995) or the inferred near-lithostatic pore pressures (Screaton et al., 1990). Fundamental difficulties lie in the extrapolation of lab measurements to large-scale systems in such low-permeability environments, particularly when flow systems may be transient in nature (Neuzil, 1986). While the limitations of the data preclude definitive hydrogeologic evaluation, the lab and in situ research efforts by Leg 156 scientists reported here contribute to understanding the factors that control hydrogeologic processes within the Barbados accretionary prism.

\section{Permeability vs. Effective Stress}

Both lab and in situ results show that permeability is dependent on effective stress (Figs. 3, 6), and therefore on pore-fluid pressure conditions. Permeability changes roughly one to two orders of magnitude for an individual sample over the range of effective stress tested. In situ tests reflect two orders of magnitude of permeability change over effective stresses of ranging from roughly 400 to $1600 \mathrm{kPa}$. The pronounced drop in permeability observed in Sample WB 15X-5 (Fig. 3A) does not show a correspondingly steep drop in void ratio (Fig. 4). Similarly, the abrupt permeability change observed in Sample AM $2 \mathrm{X}-1$ between 200 and $300 \mathrm{kPa}$ does not correspond to an abrupt change in void ratio. This suggests that some mechanism, in 
Table 2. Summary of laboratory permeability measurements and consolidation tests.

\begin{tabular}{|c|c|c|c|c|c|c|c|c|c|c|}
\hline $\begin{array}{l}\text { Core, section, } \\
\text { interval }(\mathrm{cm})\end{array}$ & $\begin{array}{c}\text { Structural } \\
\text { domain }\end{array}$ & Lithology & $\begin{array}{c}\text { Effective } \\
\text { stress } \\
(\mathrm{kPa})\end{array}$ & $\begin{array}{c}\text { Measured } \\
\text { permeability } \\
\left(\mathrm{m}^{2}\right)\end{array}$ & $\begin{array}{c}\text { Calculated } \\
\text { permeability } \\
\left(\mathrm{m}^{2}\right)\end{array}$ & $\begin{array}{l}\text { Void } \\
\text { ratio }\end{array}$ & $\begin{array}{c}P_{c}^{\prime} \\
(\mathrm{kPa})\end{array}$ & $\begin{array}{c}P_{o}^{\prime} \\
(\mathrm{kPa})\end{array}$ & OCR & Source \\
\hline \multirow{4}{*}{$\begin{array}{l}156-948 \mathrm{C}- \\
3 \mathrm{X}-3,89-102\end{array}$} & \multirow{4}{*}{ Prism } & \multirow{4}{*}{$\begin{array}{l}\text { Gray to olive- } \\
\text { gray claystone }\end{array}$} & & & & & \multirow{4}{*}{207} & \multirow{4}{*}{3348} & \multirow{4}{*}{0.06} & \multirow{4}{*}{$\mathrm{V}$} \\
\hline & & & 69 & & & 1.41 & & & & \\
\hline & & & 207 & & $1.54 \mathrm{E}-18$ & 1.4 & & & & \\
\hline & & & 2000 & & $\begin{array}{l}5.154 \mathrm{E}-18 \\
9.5 \mathrm{E}-19\end{array}$ & $\begin{array}{l}1.20 \\
1.12\end{array}$ & & & & \\
\hline \multirow[t]{3}{*}{$13 X-3,60-73$} & \multirow[t]{3}{*}{ Underthrust } & \multirow[t]{3}{*}{ Gray claystone } & 241 & $4.90 \mathrm{E}-19$ & & & \multirow{3}{*}{241} & \multirow{3}{*}{4089} & \multirow{3}{*}{0.06} & $\mathrm{~V}$ \\
\hline & & & 88 & & & 1.28 & & & & \\
\hline & & & $\begin{array}{l}241 \\
505\end{array}$ & & $\begin{array}{l}2.71 \mathrm{E}-19 \\
2.74 \mathrm{E}-19\end{array}$ & $\begin{array}{l}1.26 \\
1.16\end{array}$ & & & & \\
\hline 156-949B- & & & & & & & & & & \\
\hline $2 \mathrm{X}-1,28-42$ & Prism & Gray claystone & $85^{\mathrm{c}}$ & 4.70E- 18 & & 1.60 & & & & M \\
\hline & & & $160^{c}$ & $4.50 \mathrm{E}-18$ & & 1.54 & & & & trt \\
\hline & & & $305^{\mathrm{c}}$ & $1.66 \mathrm{E}-18$ & & 1.46 & & & & \\
\hline & & & $335^{\mathrm{p}}$ & $1.64 \mathrm{E}-18$ & & 1.46 & & & & \\
\hline & & & $420^{c}$ & $1.45 \mathrm{E}-18$ & & 1.42 & & & & \\
\hline & & & $435^{\mathrm{p}}$ & $1.30 \mathrm{E}-18$ & & 1.40 & & & & \\
\hline & & & $630^{c}$ & $1.36 \mathrm{E}-18$ & & 1.34 & & & & \\
\hline & & & $735^{\mathrm{p}}$ & $1.00 \mathrm{E}-18$ & & 1.34 & & & & \\
\hline & & & $1215^{\mathrm{p}}$ & $3.00 \mathrm{E}-19$ & & 1.26 & & & & \\
\hline $2 X-2,72-88$ & Prism & Gray claystone & 10 & $7.04 \mathrm{E}-17$ & & & & & & B \\
\hline $3 \mathrm{X}-2,87-101$ & Prism & Light olive-gray & & & & & & & & \\
\hline & & claystone & 69 & & & 1.78 & 69 & 1896 & 0.04 & $\mathrm{~V}$ \\
\hline & & & 103 & & $5.00 \mathrm{E}-18$ & 1.7 & & & & \\
\hline & & & 248 & & $1.98 \mathrm{E}-18$ & 1.58 & & & & \\
\hline & & & 455 & & $7.05 \mathrm{E}-19$ & 1.48 & & & & \\
\hline & & & 34 & & No data & 1.59 & & & & \\
\hline & & & 379 & & $3.71 \mathrm{E}-19$ & 1.51 & & & & \\
\hline & & & 690 & & $2.65 \mathrm{E}-19$ & 1.44 & & & & \\
\hline & & & 34 & & No data & 1.57 & & & & \\
\hline & & & 690 & & $4.15 \mathrm{E}-19$ & 1.44 & & & & \\
\hline & & & 876 & & $4.26 \mathrm{E}-19$ & 1.39 & & & & \\
\hline $15 X-5,28-44$ & Prism & Light olive-gray & 192 & $8.06 \mathrm{E}-16$ & & 2.28 & & & & B \\
\hline & & claystone & 384 & $4.18 \mathrm{E}-17$ & & 2.23 & & & & \\
\hline & & & 768 & $3.27 \mathrm{E}-18$ & & 2.18 & & & & \\
\hline & & & 6 & & 7.04E-15 & 2.39 & 700 & 1760 & 0.40 & \\
\hline & & & 12 & & $1.51 \mathrm{E}-15$ & 2.39 & & & & \\
\hline & & & 24 & & $1.36 \mathrm{E}-15$ & 2.38 & & & & \\
\hline & & & 48 & & $1.94 \mathrm{E}-15$ & 2.35 & & & & \\
\hline & & & 96 & & $8.48 \mathrm{E}-16$ & 2.32 & & & & \\
\hline & & & 192 & & $4.91 \mathrm{E}-16$ & 2.28 & & & & \\
\hline & & & 384 & & $2.43 \mathrm{E}-16$ & 2.23 & & & & \\
\hline & & & 768 & & $8.10 \mathrm{E}-17$ & 2.18 & & & & \\
\hline & & & 1536 & & 3.94E-18 & 2.10 & & & & \\
\hline & & & 3072 & & $6.70 \mathrm{E}-19$ & 1.98 & & & & \\
\hline 19X-1, 33-50 & Décollement & Yellowish brown & 96 & $1.12 \mathrm{E}-17$ & & 1.64 & & & & B \\
\hline & & claystone & 192 & 3.27E-18 & & 1.62 & & & & \\
\hline & & & 384 & $1.63 \mathrm{E}-18$ & & 1.59 & & & & \\
\hline & & & 96 & & $2.87 \mathrm{E}-16$ & 1.64 & 350 & 1950 & 0.18 & \\
\hline & & & 192 & & $1.63 \mathrm{E}-16$ & 1.62 & & & & \\
\hline & & & 384 & & $8.29 \mathrm{E}-17$ & 1.59 & & & & \\
\hline & & & 768 & & $4.83 \mathrm{E}-17$ & 1.53 & & & & \\
\hline & & & 1536 & & $1.51 \mathrm{E}-17$ & 1.50 & & & & \\
\hline & & & 3072 & & $1.12 \mathrm{E}-17$ & 1.44 & & & & \\
\hline & & & 6144 & & $4.56 \mathrm{E}-18$ & 1.38 & & & & \\
\hline $22 \mathrm{X}-1,130-146$ & Décollement & Light brownish & 192 & $7.86 \mathrm{E}-18$ & & 1.24 & & & & B \\
\hline & & gray claystone & 384 & $3.67 \mathrm{E}-18$ & & 1.21 & & & & \\
\hline & & & 768 & $1.12 \mathrm{E}-18$ & & 1.17 & & & & \\
\hline & & & 96 & & $3.82 \mathrm{E}-16$ & 1.26 & 200 & 2100 & 0.10 & \\
\hline & & & 192 & & $1.63 \mathrm{E}-16$ & 1.24 & & & & \\
\hline & & & 384 & & $5.47 \mathrm{E}-17$ & 1.21 & & & & \\
\hline & & & 768 & & $2.38 \mathrm{E}-17$ & 1.17 & & & & \\
\hline & & & 1536 & & $5.45 \mathrm{E}-18$ & 1.13 & & & & \\
\hline & & & 3072 & & $4.48 \mathrm{E}-18$ & 1.09 & & & & \\
\hline
\end{tabular}

Notes: OCR = overconsolidation ratio. $\mathrm{V}=$ tests results from Vrolijk, Miller, and Gooch, unpubl. data. $\mathrm{M}=$ test results from Maltman and Bolton, unpubl. data. ${ }^{\mathrm{c}}=$ tests conducted with constant confining pressure to reproduce effective stress conditions. ${ }^{\mathrm{p}}=$ tests conducted with constant pore pressure to reproduce effective stress conditions. $\mathrm{B}=$ test results from Brückmann et al., Chapter 7, this volume.

addition to reduction of porosity is responsible for changes in permeability with changing effective stress conditions.

Whereas results from these experiments cannot provide a definitive explanation for the pressure dependence of permeability, consideration of possible mechanisms can serve to direct future research efforts. It is possible that abrupt changes in permeability, without corresponding changes in porosity reflect a critical threshold that greatly alters the capacity of intra-pore pathways to transmit fluid. Although Arch and Maltman (1990) attempted to quantify the permeability increase caused by zones of reduced tortuosity in deformed clays,
Brown and Moore (1993) argued that porosity loss from collapse of clay particles following the alignment would offset any permeability increase. An alternative explanation for the abrupt behavior in Sample AM 2X-1 could be the opening/closing of microfractures (Brown, 1995). Future measurements of Barbados samples, including scaly fabric and other deformational features, could elucidate the role of structural features in influencing pressure-dependent permeability. The pronounced difference in permeability response to changes in effective stress on samples from a fault zone in the Oregon accretionary prism vs. samples from the hanging wall above the fault zone 

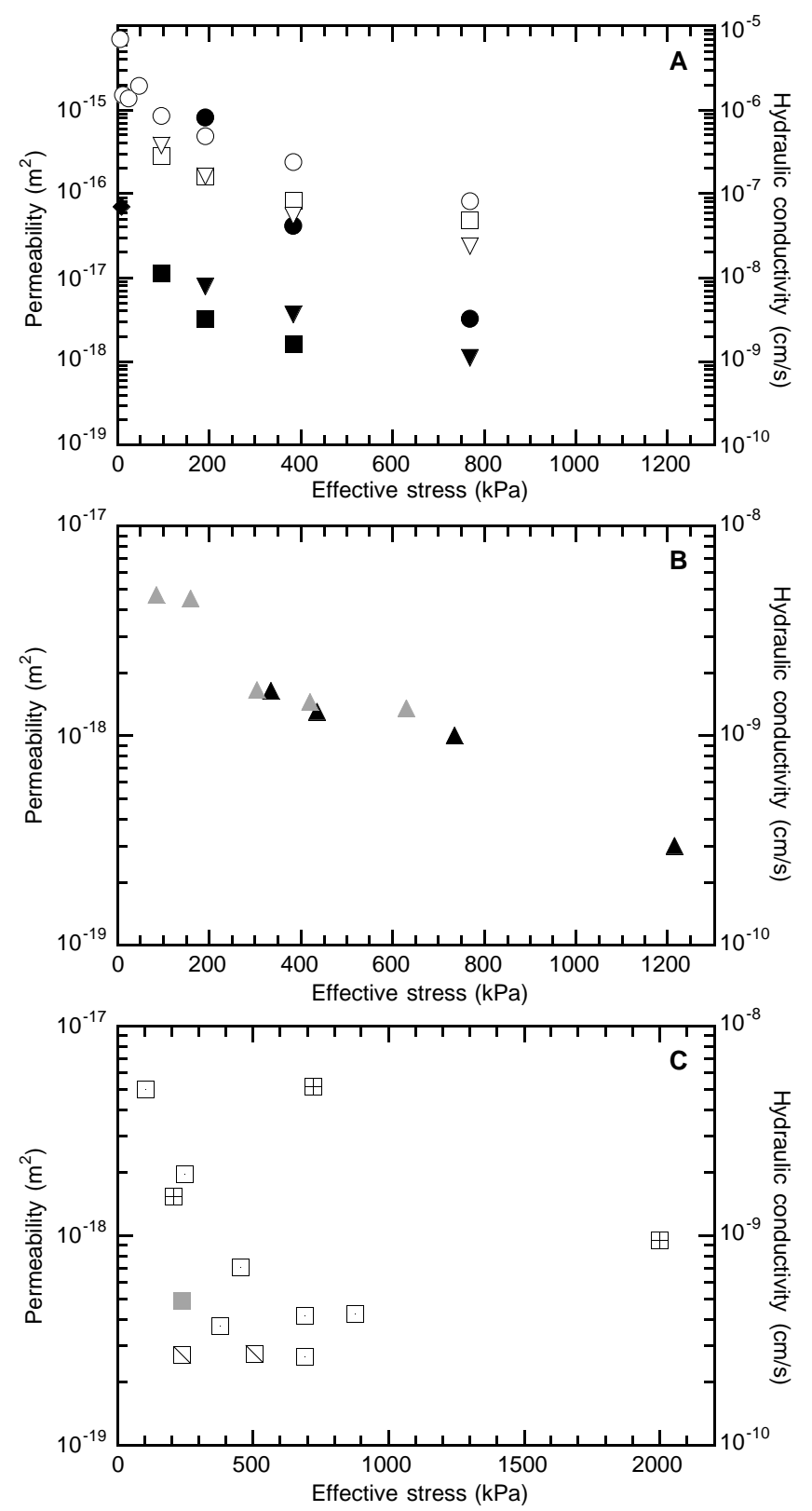

Figure 3. Plots of permeability vs. effective stress for all samples for which data are currently available. A. The diamond, circles, triangles, and squares represent data for Samples WB-2X-2, WB-15X-5, WB-19X-1, and WB$22 \mathrm{X}-1$ respectively. Solid symbols are measured values of permeability (Brückmann et al., Chapter 7, this volume). Open symbols are inferred values of permeability from consolidation response. B. All data are for Sample AM-2X-1 (A.J. Maltman, unpubl. data). The black triangles are measured permeability values for effective stress conditions with constant pore pressure. The gray triangles are measured permeability values for effective stress conditions with constant confining pressure conditions. C. The gray square is a measured permeability value for Sample PV-13X-3 (P. Vrolijk, unpubl. data). The two squares cut by a diagonal line are inferred permeability values for Sample PV-13X-3. The squares containing crosses and dots are permeability values from consolidation response for Samples PV-3X-3 and PV-3X2 , respectively.

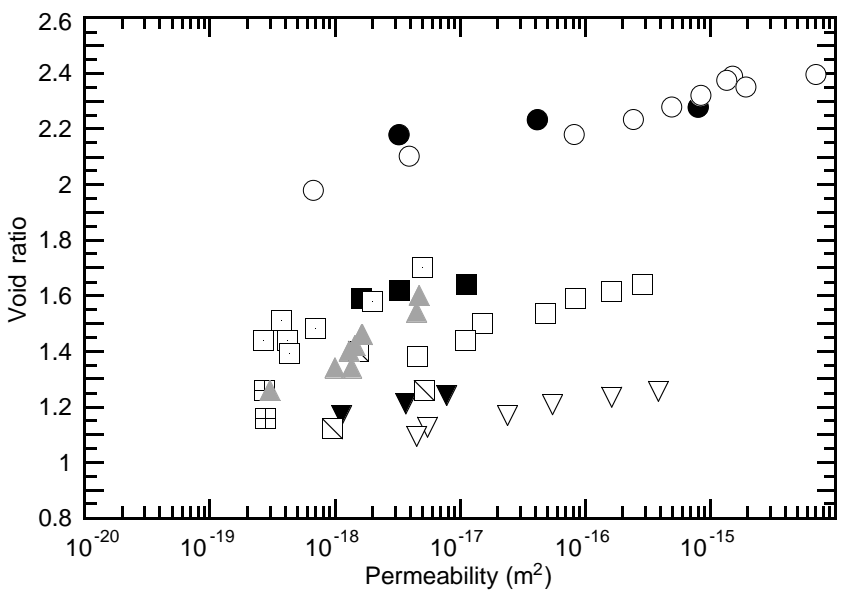

Figure 4. Plot of void ratio vs. permeability for all samples. Symbols are as for Figure 3, except that all tests on Sample AM-2X-1 are plotted as gray triangles.

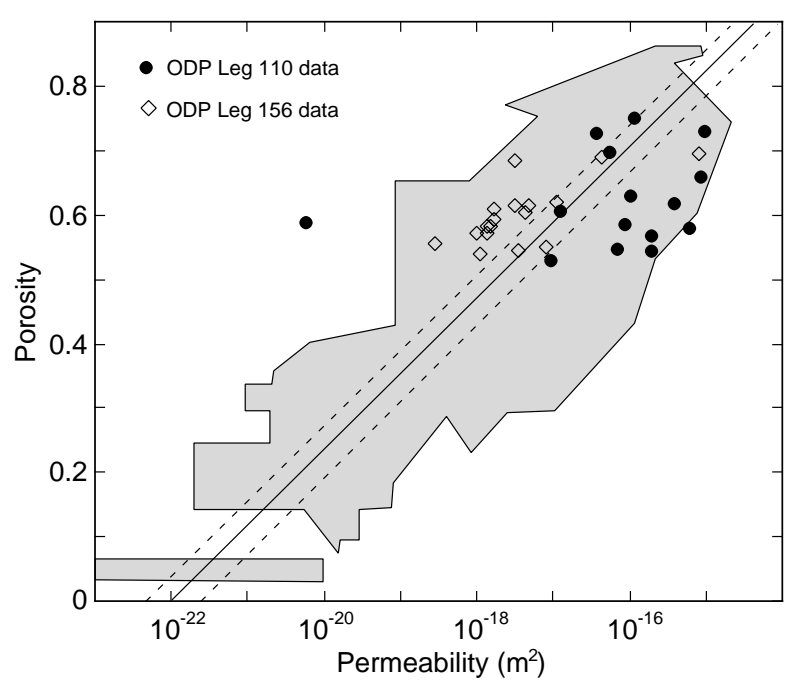

Figure 5. Plot of porosity vs. permeability (after Bekins, 1995), based on data for argillaceous formations compiled by Neuzil (1994; shaded region), Leg 110 permeability measurements are from Taylor and Leonard (1990; black circles), and porosity-permeability functions are from Bekins, et al. (1995; dashed and solid lines). Measured permeabilities from Leg 156 samples are plotted as open diamonds.

(Brown, 1995) are not evident for the Barbados samples. However, only one measurement of Barbados samples was conducted at very low effective stress magnitude, and no samples were tested that contained the scaly fabric characteristic of décollement zone deformation. A full range of effective stresses covering hydrostatic to lithostatic pore-fluid conditions should be tested. In particular, it remains to be seen whether the pressure-dependent permeability at the core scale can explain the enhanced permeability along the décollement zone.

\section{Porosity vs. Permeability}

The porosity-permeability data from Leg 156 lab measurements fall within the range of values compiled by Neuzil (1994) for argillaceous media (Fig. 5). For a given porosity value, Leg 156 permeabilities are somewhat lower than Leg 110 permeabilities. Brown and Ransom (1996) suggest that porosity values in the Barbados accre- 
Table 3. Summary of in situ permeability data from Leg 156 packer tests.

\begin{tabular}{|c|c|c|c|c|}
\hline Test & $\begin{array}{l}\text { Depth } \\
\text { (mbsf) }\end{array}$ & $\begin{array}{c}\text { Initial } \\
\text { effective stress } \\
(\mathrm{kPa})\end{array}$ & $\begin{array}{c}\text { Final } \\
\text { effective stress } \\
(\mathrm{kPa})\end{array}$ & $\begin{array}{c}\text { Bulk } \\
\text { permeability } \\
\left(\mathrm{m}^{2}\right)\end{array}$ \\
\hline \multicolumn{5}{|l|}{$156-948$} \\
\hline 1 & $472-538$ & 2685 & 2440 & $2.4 \mathrm{e}-15$ \\
\hline 2 & $472-538$ & 2860 & 2520 & $8.0 \mathrm{e}-16$ \\
\hline 3 & $472-538$ & 2372 & 3678 & $1.8 \mathrm{e}-15$ \\
\hline 4 & $472-538$ & 3208 & 2300 & $8.0 \mathrm{e}-16$ \\
\hline 6 & $472-538$ & 1268 & 1632 & $2.4 \mathrm{e}-15$ \\
\hline 7 & $472-538$ & 1485 & 1589 & $7.4 \mathrm{e}-15$ \\
\hline 8 & $472-538$ & 1384 & 1484 & $6.6 \mathrm{e}-16$ \\
\hline 9 & $472-538$ & 1148 & 1375 & $3.1 \mathrm{e}-15$ \\
\hline 10 & $472-538$ & 1148 & 621 & $3.4 \mathrm{e}-14$ \\
\hline $11 \mathrm{~A}$ & $472-538$ & 647 & 691 & $6.9 \mathrm{e}-14$ \\
\hline $11 \mathrm{~B}$ & $472-538$ & 895 & 1031 & $7.3 e-15$ \\
\hline $12 \mathrm{~A}$ & $472-538$ & 1017 & 637 & 7.0e-14 \\
\hline $12 \mathrm{~B}$ & $472-538$ & 637 & 412 & $9.2 \mathrm{e}-14$ \\
\hline 13 & $472-538$ & 451 & 559 & $9.7 \mathrm{e}-14$ \\
\hline $14 \mathrm{~A}$ & $472-538$ & 591 & 405 & $6.1 \mathrm{e}-14$ \\
\hline 14B & $472-538$ & 394 & 276 & $1.0 \mathrm{e}-13$ \\
\hline $15 \mathrm{~A}$ & $472-538$ & 118 & 141 & $3.5 e-13$ \\
\hline $15 \mathrm{~B}$ & $472-538$ & 172 & 207 & $5.5 \mathrm{e}-14$ \\
\hline \multicolumn{5}{|l|}{$156-949$} \\
\hline 1 & $392-463$ & 1456 & 1721 & $8.6 e-16$ \\
\hline 5 & $392-463$ & 2058 & 2182 & $6.4 \mathrm{e}-16$ \\
\hline 8 & $387-463$ & 775 & 406 & $6.9 \mathrm{e}-15$ \\
\hline $9 \mathrm{~A}$ & $387-463$ & 423 & 429 & $7.9 \mathrm{e}-14$ \\
\hline $9 \mathrm{~B}$ & $387-463$ & 490 & 538 & $7.5 e-15$ \\
\hline 10 & $387-463$ & 801 & 957 & $1.2 \mathrm{e}-15$ \\
\hline 11 & $387-463$ & 892 & 997 & $2.0 \mathrm{e}-15$ \\
\hline 12 & $387-463$ & 569 & 250 & $2.7 \mathrm{e}-14$ \\
\hline 13 & $387-463$ & 306 & 386 & $1.1 \mathrm{e}-13$ \\
\hline
\end{tabular}

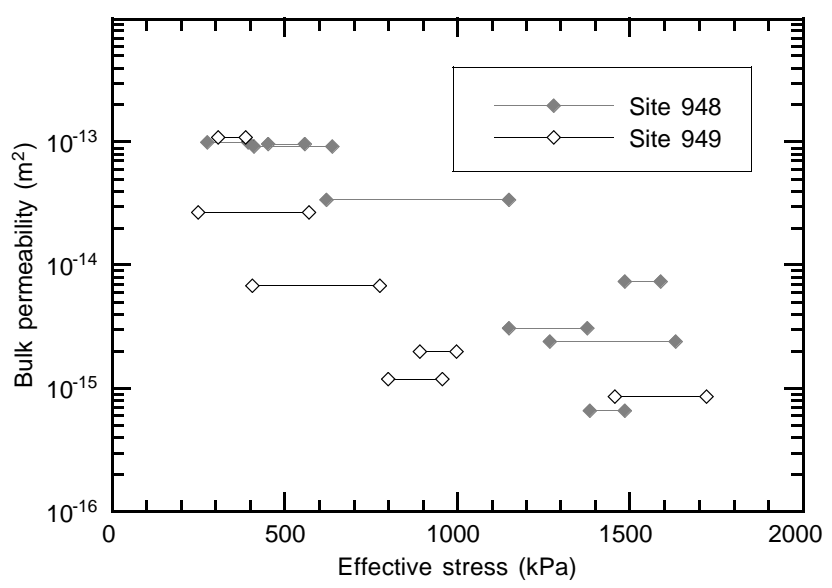

Figure 6. Plot of bulk permeability vs. effective stress, including only data from the most reliable in situ tests conducted at Sites 948 and 949 (Fisher and Zwart, Chapter 15, this volume). Lines connect the minimum and maximum effective stress for each test.

tionary prism are overestimated due to the presence of hydrated minerals (i.e., smectite). It may be necessary to reevaluate "true" porosity for Leg 156 samples that have variable smectite content. Whereas porosity is certainly an important factor in controlling permeability, indications of overpressured pore fluids necessitate examination of other factors that might influence permeability at low effective stresses.

\section{Scale Effects}

The pronounced difference in magnitude between lab and in situ permeability values (Fig. 7) may indicate that core-scale measurements are unable to sample structural features, such as networks of microfractures or scaly fabric, which provide dynamic, pressuredependent, and perhaps transient pathways for fluid flow at the regional scale. In fact, Leg 156 laboratory samples tested were preferentially selected to avoid fractures and are likely to reflect matrix permeability. In situ measurements on the other hand, clearly test in-

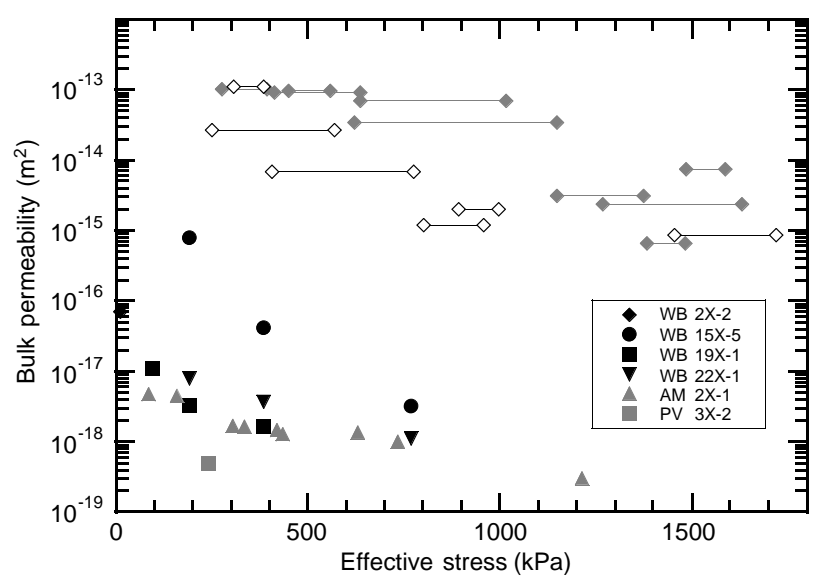

Figure 7. Plot of permeability vs. effective stress for both in situ and laboratory permeability data at Sites 948 and 949. Symbols are as for Figures 3 and 6. Calculated permeability values, based on consolidation response, are not included. Gray diamonds are values for Site 948. Open diamonds are values for Site 949.

tervals that include zones of intense scaly fabric, and faults that can act as conduits for focused fluid flow (Moore, 1989) The short duration of the in situ tests could overestimate bulk permeability values. Alternatively, future measurements at the core scale, at very low effective stresses (less than $100 \mathrm{kPa}$ ), could reveal pronounced increases in permeability. However, it is likely that the difference in magnitudes at lab and in situ scales reflects deformational processes, which serve to contribute to the observed localization of fluid flow along the décollement zone of the Barbados accretionary prism. Similar scale differences are evident within a fault zone in the Oregon accretionary prism (Screaton et al., 1995).

\section{CONCLUSIONS}

Permeability within the Barbados accretionary prism is scale dependent. Lab measurements of permeability range over almost four orders of magnitude $\left(3 \mathrm{e}-19\right.$ to $\left.8 \mathrm{e}-16 \mathrm{~m}^{2}\right)$ for effective stresses within the 10-1205 $\mathrm{kPa}$ range. Fault permeability ranges over two orders of magnitude $\left(1 \mathrm{e}-15\right.$ to $\left.1 \mathrm{e}-13 \mathrm{~m}^{2}\right)$ within the same effective stress range (Fig. 7). Because samples were relatively undeformed, lab measurements are likely to reflect matrix permeability. On the other hand, in situ tests clearly include the décollement zone and are indicative of the magnitude of fault-zone permeability. Although it is possible that in situ measurements may overestimate fault permeability, the direct measurements of permeability indicate that faultzone permeability is indeed 3-5 orders of magnitude greater than matrix permeability.

In addition, both matrix-scale and formation-scale permeability appear to be pressure dependent. Permeability values change orders of magnitude as fluid pressures vary between hydrostatic and lithostatic values. In situ tests and consolidation test results, as well as indirect lines of evidence (Tobin and Moore, Chapter 9, this volume; Moore et al., 1995), indicate that pore-fluid pressures approach lithostatic values at multiple locations within the Barbados accretionary prism. Further research is needed to determine the mechanisms responsible for the pressure dependence of permeability at all scales.

\section{ACKNOWLEDGMENTS}

This manuscript benefited from the thoughtful comments of John Bredehoeft and an anonymous reviewer. In addition, suggestions from Barbara Bekins and Brian MacAdoo were particularly helpful. 


\section{REFERENCES}

Arch, J., and Maltman, A.J., 1990. Anisotropic permeability and tortuosity in deformed wet sediments. J. Geophys. Res., 95:9035-9046.

Atkinson, J.H., and Bransby, P.L., 1978. The Mechanics of Soils: An Introduction to Critical State Soil Mechanics: London (McGraw-Hill).

Bekins, B.A., McCaffrey, A.M., and Dreiss, S.J., 1995. Episodic and constant flow models for the origin of low-chloride waters in a modern accretionary complex. Water Resour. Res., 31:3205-3215.

Brown, K.M., 1995. The variation of the hydraulic conductivity structure of an overpressured thrust zone with effective stress. In Carson, B., Westbrook, G.K., Musgrave, R.J., and Suess, E. (Eds.), Proc. ODP, Sci. Results, 146 (Pt. 1): College Station, TX, (Ocean Drilling Program), 281-289.

Brown, K.M., and Moore, J.C., 1993. Comment on "Anisotropic permeability and tortuosity in deformed wet sediments" by J. Arch and A. Maltman. J. Geophys. Res., 98:17,859-17,864.

Brown, K.M., and Ransom, B., 1996. Porosity corrections for smectite-rich sediments; impact on studies of compaction, fluid generation, and tectonic history. Geology, 24:843-846.

Fisher, A.T., and Hounslow, M.W., 1990. Heat flow through the toe of the Barbados accretionary complex. In Moore, J.C., Mascle, A., et al., Proc. ODP, Sci. Results, 110: College Station, TX (Ocean Drilling Program), 345-363.

Holtz, R.D., and Kovacs, W.D., 1981. An Introduction to Geotechnical Engineering: Englewood Cliffs, NJ (Prentice-Hall).

Hubbert, M.K., and Rubey, W.W., 1959. Role of fluid pressure in mechanics of overthrust faulting, I. Mechanics of fluid-filled porous solids and its application to overthrust faulting. Geol. Soc. Am. Bull., 70:115-166.

Lambe, T.W., and Whitman, R.V., 1969. Soil Mechanics: New York (Wiley).

Moore, J.C., 1989. Tectonics and hydrogeology of accretionary prisms: role of the décollement zone. J. Struct. Geol., 11:95-106.

Moore, J.C., Shipley, T.H., Goldberg, D., Ogawa, Y., Filice, F., Fisher, A., Jurado, M.J., Moore, G.F., Rabaute, A., Yin, H., Zwart, G., Brückmann, W., Henry, P., Ashi, J., Blum, P., Meyer, A., Housen, B., Kastner, M., Labaume, P., Laier, T., Leitch, E.C., Maltman, A.J., Peacock, S., Steiger,
T.H., Tobin, H.J., Underwood, M.B., Xu, Y., and Zheng, Y., 1995. Abnormal fluid pressures and fault-zone dilation in the Barbados accretionary prism; evidence from logging while drilling. Geology, 23:605-608.

Neuzil, C.E., 1986. Groundwater flow in low permeability environments. Water Resour. Res., 22:1163-1195.

1994. How permeable are clays and shales? Water Resour. Res., 30:145-150.

Olsen, H.W., Nichols, R.W., and Rice, T.L., 1985. Low gradient permeability measurements in a triaxial system. Geotechnique, 35:145-157.

Screaton, E.J., Carson, B., and Lennon, G.P., 1995. Hydrogeologic properties of a thrust fault within the Oregon accretionary prism. J. Geophys. Res., 100:20025-20036.

Screaton, E.J., Wuthrich, D.R., and Dreiss, S.J., 1990. Permeabilities, fluid pressures, and flow rates in the Barbados Ridge Complex. J. Geophys.Res., 95:8997-9007.

Shipboard Scientific Party, 1995a. Site 948. In Shipley, T.H., Ogawa, Y., Blum, P., et al., Proc. ODP, Init. Repts., 156: College Station, TX (Ocean Drilling Program), 87-192.

, 1995b. Site 949. In Shipley, T.H., Ogawa, Y., Blum, P., et al., Proc. ODP, Init. Repts., 156: College Station, TX (Ocean Drilling Program), 193-257.

Stein, S., DeMets, C., Gordon, R.G., Brodholt, J., Argus, D., Engeln, J.F., Lundgren, P., Stein, C., Wiens, D.A., and Woods, D.F.A., 1988. A Test of alternative Caribbean plate relative motion models. J. Geophys. Res., 93:3041-3050.

Taylor, E., and Leonard, J., 1990. Sediment consolidation and permeability at the Barbados forearc. In Moore, J. C., Mascle, A., et al., Proc. ODP, Sci. Results, 110: College Station, TX, (Ocean Drilling Program), 289-308.

Vrolijk, P., Fisher, A., and Gieskes, J., 1991. Geochemical and geothermal evidence for fluid migration in the Barbados accretionary prism (ODP Leg 110). Geophys. Res. Lett., 18:947-950.

Date of initial receipt: 1 August 1996

Date of acceptance: 7 January 1997

Ms 156SR-036 